\title{
Myastenie gravis
}

\section{MUDr. Stanislav Voháňka, CSc., MBA - editor hlavního tématu Neuromuskulární centrum, Neurologická klinika LF MU a FN, Brno}

Myastenie patří mezi vzácné nemoci, i když v okruhu neuromuskulárních poruch patří mezi nejčastější. Přesná prevalence a incidence v Česku není známa a pohybujeme se v širokém rozpětí literárních údajů (Carr et al., 2010; McGrogan et al., 2010; Lavrnic et al., 2013). Také není jasné, zda dochází ke zvyšování incidence, nebo zda jde jen o lepší záchyt (Pedersen et al., 2013). Bližší informace o situaci v Česku by mohl v budoucnu dát registr nemocných, který jsme pred časem spustili (http://myreg.registry.cz/). Panuje všeobecná shoda, že registry jsou významným nástrojem rízení a zkvalitňování péče. Neformálním způsobem vedou k určité standardizaci, ukazují na tvrdých datech práci jednotlivých center a v neposlední řadě jsou vizitkou naší práce navenek. S plynoucím časem význam a cena dat v registrech stoupá. Troufám si neskromně ríci, že vytvořením registru jsme založili zdroj dat pro budoucí generaci neuromuskulárních expertů.

Ke správné klinické praxi i dlouhodobému sledování patřri standardizované škálování, které umožňuje sledování nemocných v čase i skupinové porovnávání. V př́padě myastenie - tedy choroby, u které príznaky významně fluktuují - je konstrukce, validace a výběr adekvátní klinimetrie delikátním problémem. Pro získání plastického a priliéhavého obrazu potřebujeme jak údaje okamžité, tak intervalové. Mohli bychom to prirrovnat k fotografické momentce a videu... Navíc kombinujeme objektivní měření se subjektivním hod-

\section{LITERATURA}

1. Carr AS, Cardwell CR, McCarron PO, McConville J. A systematic review of population based epidemiological studies in Myasthenia Gravis. BMC Neurol. 2010; 10: 46.

2. Lavrnic D, Basta I, Rakocevic-Stojanovic V, Stevic Z, Peric S, Nikolic A, Marjanovic l, Pekmezovic T. Epidemiological study of adult-onset myasthenia gravis in the area of Belgrade (Serbia) in the period 1979-2008. Neuroepidemiology 2013; 40: 190-194. 3. McGrogan A, Sneddon S, de Vries CS. The incidence of myasthenia gravis: a systematic literature review. Neuroepidemiology 2010; 34: 171-183. nocením pacienta a hledáme přiměřenou citlivost k signifikantním změnám. Samozřejmým předpokladem je národní jazyková lokalizace a validace.

Kvalita péče o nemocné s myastenií je u nás tradičně na velmi dobré úrovni. Dlouhou tradici má operační léčba pomocí tymektomie, i když exaktní důkaz o její účinnosti by podán teprve nedávno (Wolfe et al., 2016). Postupy imunosupresivní léčby se v různých zemích značně liší a odráží určité zvyky a tradice, o jejichž původu můžeme pouze spekulovat (dominantní používání kalcineurinových inhibitorů v Japonsku apod.). Použivání většiny imunosupresiv nemá pevné ukotvení v klinických studiích a někteří autoři či národní standardy je připouštění pouze jako „steroid sparing agents". Reálná každodenní klinická praxe nás ale přesvědčuje o jejich efektivitě. S jejich použiváním by ale měla být spojena dobrá znalost dávkování a nežádoucích účinků jak krátko-, tak dlouhodobých. Z monoklonálních protilátek jsme dosud měli u refrakterních forem $\mathrm{k}$ dispozici pouze rituximab (chimérická monoklonální protilátka anti CD20). Eculizumab (humanizovaná monoklonální protilátka proti komplementovému proteinu (5), který byl dosud používán u paroxyzmální noční hemoglobinurie a atypického hemolyticko uremického syndromu, prokázal v klinické studii REGAIN jasně svoji účinnost a byl již hlavními lékovými regulátory povolen pro léčbu ACHR pozitivní refrakterní myastenie. V iniciálních fázích výzkumu je celá řada dalších nových postupů.

4. Pedersen EG, Hallas J, Hansen K, Jensen PEH, Gaist D. Late-onset myasthenia not on the increase: a nationwide register study in Denmark, 1996-2009. Eur. J. Neurol. 2013; 20: 309-314. 5. Stålberg E, Sanders DB, Ali S, Cooray G, Leonardis L, Löseth S, Machado F, Maldonado A, Martinez-Aparicio C, Sandberg A, Smith B, Widenfalk J, Aris Kouyoumdjian J. Reference values for jitter recorded by concentric needle electrodes in healthy controls: a multicenter study. Muscle Nerve 2016; 53: 351-362. 6. Wolfe Gl, Kaminski HJ, Aban IB, Minisman G, Kuo H-C, Marx A, Ströbel P, Mazia C, Oger J, Cea JG, Heckmann JM
Diagnosticky převládá pocit, že vše již bylo řečeno, ale není tomu tak. V oblasti elektrofyziologie došlo v posledních letech k prechodu k používání jednorázových koncentrických elektrod při vyšetřování jednoho svalového vlákna. Otcem této modifikace byl samozřejmě (jak jinak) Erik Stalberg, který publikoval i rozsáhlý metodický a normotvorný materiál (Stålberg et al., 2016). Pátrání po další patogenetické protilátce bylo zatím, přes všechno vynaložené úsilí, marné. Zbývá tak i při použití vysoce sofistikovaných metod (nizkodenzitní protilátky na tkáňových kulturách) určitě procento seronegativnich pacientů. Otázkou zůstává, zda některé prípady myastenie s negativními protilátkami v mladém věku nejsou ve skutečnosti nepoznané kongenitální myastenie. Dnes v době dobré dostupnosti pokročilých metod sekvenování to určitě stojí alespoň za úvahu.

V managementu myastenie zůstává trvale obávanou situací nutnost operace a celkově anestezie. Ne vždy jsou obavy na místě, vždy však je nutná předběžná opatrnost. Moderní anesteziologické postupy a šetrné metody miniinvazivní chirurgie významně zlepšily bezpečnost a prognózu nemocných s myastenií. Problém intenzivní medicíny a lékových interakcí spočivá ve faktu, že nemáme kontrolované pokusy, ale pouze pozorování, kazuistiky a prenesené údaje z experimentů na zviřatech. Ale i zde lze formulovat určitá doporučení a využít některé nové léky ve prospěch nemocných.

Evoli A, Nix W, Ciafaloni E, Antonini G, Witoonpanich R, King JO, Beydoun SR, Chalk CH, Barboi AC, Amato AA, Shaibani Al, Katirji B, Lecky BR, Buckley C, Vincent A, Dias-Tosta E, Yoshikawa $\mathrm{H}$, Waddington-Cruz M, Pulley MT, Rivner MH, Kostera-Pruszczyk A, Pascuzzi RM, Jackson CE, Garcia Ramos GS, Verschuuren JJ, Massey JM, Kissel JT, Werneck LC, Benatar M, Barohn RJ, Tandan R, Mozaffar T, Conwit R, Odenkirchen J, Sonett JR, Jaretzki A $3^{\text {rd }}$, Newsom-Davis J, Cutter GR; MGTX Study Group. Randomized trial of thymectomy in myasthenia gravis. N. Engl. J. Med. 2016; 375: 511-522. 